\title{
Evaluasi Pertumbuhan Suspensi Sel Dendrobium anosmum var. gigantea dan Aktivitasnya sebagai Antioksidan
}

\author{
Yanuar Prasetyo, Kristian Njudang, Handriyanto Mulyono Putra Wibowo, Alfian Hendra \\ Krisnawan
}

Departemen Biologi Farmasi, Fakultas Farmasi, Universitas Surabaya, Surabaya, Indonesia

Korespondensi: Alfian Hendra Krisnawan

Email: alfian_hendra_k@staff.ubaya.ac.id

Submitted : 30-08-2020, Revised :10-12-2020, Accepted : 22-12-2020

\begin{abstract}
ABSTRAK: Dendrobium merupakan tumbuhan anggrek yang memiliki manfaat bagi kesehatan dan termasuk dalam pengobatan China. Dendrobium anosmum var. gigantea dapat dikembangan dengan metode kultur jaringan tumbuhan karena memiliki sifat totipotensi. Pertumbuhan Kultur suspensi sel dapat dipengaruhi oleh kondisi lingkungan maupun komposisi media kultur. Sangat penting dilakukan optimasi untuk mendapatkan pertumbuhan yang baik. Penelitian ini dilakukan untuk melihat pengaruh konsentrasi massa dalam flash sha$\operatorname{ker}(10 \mathrm{mg} / 10 \mathrm{ml} ; 10 \mathrm{mg} / 20 \mathrm{ml}$; dan $10 \mathrm{mg} / 30 \mathrm{ml})$ dan konsentrasi sukrosa media dalam bioreaktor (30 g/l; $35 \mathrm{~g} / \mathrm{l} ; 40 \mathrm{~g} / \mathrm{l}$ ) terhadap pertumbuhan suspensi sel Dendrobium anosmum var. gigantea. Skrining fitokimia dan uji aktivitas antioksidan dilakukan untuk mengetahui golongan senyawa serta aktivitas ekstrak sebagai antioksidan. Media yang digunakan diperkaya dengan menggunakan hormon pertumbuhan NAA (Naftalen Asam Asetat) : BAP (Benzil Amino Purin) 0,5 ppm : 0,5 ppm. Skrining fitokimia dilakukan menggunakan metode spot test. Akivitas antioksidan diuji dengan menggunakan metode DPPH. Hasil pengamatan menunjukkan pertumbuhan suspensi sel pada flash shaker dengan konsentrasi $10 \mathrm{mg} / 30 \mathrm{ml}$ dan pada bioreaktor dengan sukrosa $35 \mathrm{~g} / \mathrm{l}$ memberikan hasil yang paling optimal. Aktivitas antioksidan dari kultur suspensi sel memiliki nilai IC $_{50}$ lebih baik dibandingkan tanaman induk yaitu 53.930 ppm, namun masih diktegorikan sangat lemah.
\end{abstract}

Kata kunci: Antioksidan; Bioreaktor; Dendrobium anosmum var. gigantea; Kultur suspensi sel

ABSTRACT: Dendrobium is an orchid plant that has health benefits and included in traditional Chinese medicine. Dendrobium anosmum var. gigantea can be developed using the plant tissue culture method because it has totipotential properties. The growth of cell suspension cultures can be influenced by environmental conditions and the composition of the culture media. Optimization is needed so that optimal growth can be obtained. This study was conducted to see the effect of mass concentration in a flash shaker (10 mg / $10 \mathrm{ml} ; 10 \mathrm{mg} / 20 \mathrm{ml}$; and $10 \mathrm{mg} / 30$ $\mathrm{ml}$ ) and the concentration of sucrose media in the bioreactor $(30 \mathrm{~g} / \mathrm{l} ; 35 \mathrm{~g} / \mathrm{l} ; 40 \mathrm{~g} / \mathrm{L})$ on the growth of Dendrobium anosmum var. gigantea cell suspension. Phytochemical screening and antioxidant activity tests were carried out to determine the class of compounds and extract activity as antioxidants. The media used is enriched using the growth hormone NAA (Naphthalene Acetic Acid) : BAP (Benzyl Amino Purine) 0.5 ppm : 0.5 ppm. Phytochemical screening was carried out using the spot test method. Antioxidant activity was tested using the DPPH method. The results showed that the growth of cell suspension on a flash shaker with a concentration of $10 \mathrm{mg} / 30 \mathrm{ml}$ and a bioreactor with $35 \mathrm{~g} / \mathrm{l}$ sucrose showed the most optimal results. The antioxidant activity of the cell suspension culture has a better $I C_{50}$ value than the parent plant, namely 53,930 ppm, but it is still categorized as very weak.

Keywords: Antioxidant; Bioreactor; Cell suspension culture; Dendrobium anosmum var. gigantea 


\section{Pendahuluan}

Dendrobium merupakan genus tanaman terbesar ketiga dari famili Orchidaceae yang memiliki 1184 spesies di dunia [1]. Genus ini telah lama digunakan dalam pengobatan tradisional China (TCM). Penelitian yang pernah dilakukan pada beberapa spesies Dendrobium didapatkan bahwa $D$. pharisii memliki efek antioksidan dan anti inflamasi [2] , D. candidum dapat menghambat proliferasi dan menginduksi apoptosis sel kanker [3], D. chrysotoxum dapat meringankan diabetic retinophati dan memperbaiki inflamasi pada retina [4], D. formosum dapat digunakan sebagai antidiabetes dan antiobesitas [5]. Dilaporkan bahwa hampir seluruh genus Dendrobium mengandung alkaloid dendrobin [6]. Dendrobium anosmum var. gigantea memiliki kandungan golongan senyawa alkaloid, flavonoid, tanin, dan fenol [7].

Perbanyakan tanaman anggrek secara konvensional membutuhkan waktu yang cukup lama karena laju multiplikasi yang lambat serta memerlukan waktu yang lama dalam penyediaan bibit [8]. Teknik kultur jaringan tanaman menjadi alternatif untuk mengembangkan tumbuhan anggrek. Kalus merupakan sel tanaman yang dapat diperoleh pada hampir seluruh bagian tanaman dan bisa bertahan dalam jangka waktu yang lama dalam lingkungan yang sesuai [9]. Kultur suspensi sel kalus dapat digunakan untuk mendapatkan massa sel yang lebih banyak untuk kebutuhan produksi metabolit sekunder maupun penelitian tingkat lanjut. Pertumbuhan suspensi sel yang optimal memerlukan kondisi kultur maupun komposisi media yang optimal [10]. Penelitian yang dilakukan sebelumnya terhadap lingkungan kultur sel maupun komposisi media yang digunakan menghasilkan pertumbuhan sel yang berbeda. Perbedaan jenis, konsentrasi, dan kombinasi antara zat pengatur tumbuh dan jenis media akan menghasilkan pertumbuhan yang berbeda [11]. Konsentrasi sukrosa yang digunakan memiliki nilai optimal agar dapat menghasilkan biomassa sel yang optimal [12]. Penelitian yang dilakukan Lim et al. [13] menunjukkan bahwa perbedaan massa sel yang dikultur menghasilkan pertumbuhan yang berbeda.

Pada dasarnya kultur suspensi sel dilakukan menggunakan erlenmeyer dan diagitasi menggunakan alat shaker. Pertumbuhan suspensi sel di dalam erlenmeyer terbatas pada jumlah yang kecil, namun metode ini dapat digunakan sebagai inisiai kultur suspensi sel. Guna memenuhi kebutuhan dengan jumlah yang lebih besar maka diperlukan pengembangan metode atau scale-up menggunakan bioreaktor [10]. Kondisi pertumbuhan yang optimal dapat dicapai menggunakan bioreaktor karena beberapa parameter seperti tekanan hidrodinamik/aerasi, suhu, $\mathrm{pH}$, oksigen terlarut dll. dapat dikontrol [14]. Sampai saat ini baru sedikit studi yang dilakukan untuk melihat pertumbuhan suspensi sel kalus Dendrobium anosmum var. gigantea dalam bioreaktor.

Dendrobium anosmum var. gigantea berpotensi dikembangkan dengan cara kultur jaringan tumbuhan. Pada studi ini telah diteliti bagaimana pertumbuhan suspensi sel Dendrobium anosmum var. gigantea dalam flash shaker dengan konsentrasi massa yang berbeda yaitu $10 \mathrm{mg} / 10 \mathrm{ml}$; $10 \mathrm{mg} / 20 \mathrm{ml}$; dan $10 \mathrm{mg} / 30 \mathrm{ml}$ pada labu erlenmeyer serta pertumbuhan suspensi sel dalam bioreaktor dengan perbedaan konsentrasi sukrosa yaitu 30 g/l; 35 g/l; dan 40 g/l. Hasil kultur suspensi sel yang didapatkan kemudian dihitung parameter pertumbuhannya antara lain bobot basah, SCV (Settled Cell Volume), PCV (Peacked Cell volume), dan indeks pertumbuhan. Dalam uraian di atas disebutkan bahwa Dendrobium anosmum var. gigantea memiliki kandungan akaloid, flavonoid, dan fenol yang merupakan substansi antioksidan alami. Dalam penelitian ini untuk melihat potensi aktivitas antioksidan suspensi sel Dendrobium anosmum var. gigantea dibandingkan dengan tanaman induknya, kultur suspensi sel dikumpulkan dan diekstraksi menggunakan etanol lalu dilakukan skrining golongan senyawa dan pengujian aktivitas antioksidan mengguna- 
kan metode DPPH.

\section{Metode}

\subsection{Bahan tanaman dan pembentukan kultur suspensi sel}

Bahan tanaman yang digunakan merupakan kultur sel Dendrobium anosmum var. gigantea yang dibiakkan di Laboratorium Bioteknologi Farmasi, Fakultas Farmasi, Universitas Surabaya. Kultur sel yang digunakan telah dilakukan inisiasi ke dalam media cair MS (Murashige and Skoog) dengan penambahan hormon pertumbuhan NAA 0,5 ppm : BAP 0,5 ppm dan sukrosa 30g/l dengan rentang $\mathrm{pH}$ 5,6 - 5,7. Kultur suspensi sel telah disubkultur/pasase sebanyak 3 kali setiap 7 hari. Proses inisiasi serta subkultur suspensi sel dilakukan dengan memindahkan sel ke dalam media cair steril secara aseptis di dalam laminar air flow cabinet. Sterilisasi media kultur dilakukan menggunakan autoklav suhu $121^{\circ} \mathrm{C}$ selama 15 menit. Semua kultur suspensi sel disimpan di dalam ruang inkubasi pada suhu 27 $29^{\circ} \mathrm{C}$ serta dilakukan agitasi dengan kecepatan 50 rpm. Eksplan yang digunakan dalam penelitian ini merupakan sel yang berwarna hijau hasil dari pasase ke-3. Metode diadaptasi dari Sholikah (2018) [15].

\subsection{Kultivasi suspensi sel dalam flash shaker dengan konsentrasi massa berbeda}

Sebanyak $3 \mathrm{mg}$ sel Dendrobium anosmum var. gigantea diambil dan dimasukkan ke dalam erlenmeyer berisi media cair MS yang mengandung NAA : BAP (0,5 ppm : 0,5 ppm) dengan volume yang berbeda $(10 \mathrm{ml}, 20 \mathrm{ml}, 30$ $\mathrm{ml}$ ). Proses kultivasi dilakukan dalam kondisi aseptis di dalam LAF. Kultur suspensi sel disimpan di atas rotary shaker dengan kecepatan $50 \mathrm{rpm}$, di bawah cahaya lampu TL \pm 1000 lux dengan suhu $24-26^{\circ} \mathrm{C}$. Kultur dikultivasi selama 14 hari. Profil pertumbuhan diamati berdasarkan parameter morfologi, mikroskopis, pengukuran Indeks Pertumbuhan (IP), Settled Cell Volume (SCV), dan Packed Cell Volume (PCV). Pengamatan dilakukan pada hari ke-0, 7 dan 14. Metode diadaptasi dari
Yonathan (2019) [16].

\subsection{Kultivasi suspensi sel dalam bioreaktor dengan perbedaan kosentrasi sukrosa}

Untuk melihat pertumbuhan suspensi sel D. anosmum var. gigantea dengan perbedaan konsentrasi sukrosa di dalam sistem bioreaktor, suspensi sel dikultur didalam media MS dengan NAA : BAP (0,5 ppm : 0,5 ppm) dengan 3 variasi konsentrasi sukrosa yaitu 30, 35, dan $40 \mathrm{~g} / \mathrm{l}$. Proses kultivasi menggunakan bioreaktor tipe bubble column berkapasitas $500 \mathrm{ml}$ yang telah disterilisasi dan dilakukan secara aseptis di dalam LAF. Bobot sel awal yang digunakan sebanyak $100 \mathrm{mg}$ dalam $250 \mathrm{ml}$ media. Suspensi sel yang telah dikultivasi di dalam bioreaktor disimpan pada ruang inkubasi selama 14 hari dengan diberikan aerasi sebesar 0,6 l/menit. Setelah 14 hari diamati secara organoleptis, mikroskopis, dan diukur pertumbuhan sel berdasarkan SCV, bobot basah, dan indeks petumbuhan. Metode diadaptasi dari Mauana (2019) [17].

\subsection{Pengukuran parameter pertumbuhan}

Pertumbuhan sel kalus diukur berdasarkan nilai IP, SCV, dan PCV. Selain itu kualitas sel kalus yang dihasilkan juga dilihat berdasarkan pengamatan organoleptis dan mikroskopis. Pengukuran IP dilakukan dengan membandingkan bobot basah sesudah dan sebelum kultivasi. Suspensi sel dipisahkan dari media tumbuh melalui penyaringan menggunakan kertas saring Whatman No. 1 lalu dibilas menggunakan aquadem. Sel yang didapatkan ditimbang dan ditetapkan sebagai bobot basah sel setelah kultivasi.

Settled Cell Volume (SCV) dihitung dengan membandingkan volume sel yang mengendap dengan volume media cair. Suspensi sel dipindahkan ke dalam gelas ukur dan dibiarkan mengendap selama 30 menit, fraksi endapan sel dibandingkan dengan volume media dan dihitung sebagai volume endapan sel. Packed Cell Volume (PCV) dilakukan dengan memindahkan suspensi sel kalus pada tabung sentrifus yang telah 
Tabel 1. Metode skrining fitokimia

\begin{tabular}{lll}
\hline Golongan senyawa & Pereaksi & Hasil (+) \\
\hline Alkaloid & Dragendorf [19] & Endapan warna merah \\
Steroid & Asam asetat anhidrida $+\mathrm{H}_{2} \mathrm{SO}_{4}$ pekat [19] & Warna biru dan hijau \\
Terpenoid & Asam asetat anhidrida $+\mathrm{H}_{2} \mathrm{SO}_{4}$ pekat [19] & Ungu, hijau biru \\
Saponin & Aquadem dikocok kuat [20] & Busa stabil \\
Fenol & $\mathrm{FeCl}_{3}[19]$ & Hijau hingga biru hitam \\
Tannin & $\mathrm{FeCl}_{3}[19]$ & Endapan biru hitam \\
Flavonoid & $2-3$ tetes etanol + serbuk $\mathrm{Mg}+$ beberapa tetes $\mathrm{HCl} 5 \mathrm{M} \mathrm{[19]}$ & Warna merah lembayung \\
\hline
\end{tabular}

dikalibrasi. Suspensi sel disentrifugasi selama 5 menit, pada suhu $25^{\circ} \mathrm{C}$ (suhu ruangan) dengan kecepatan 2.000 rpm. Volume endapan sel setelah sentrifus dibandingkan dengan volume media dan dihitung sebagai nilai PCV. Metode ini diadaptasi dari Farjaminezhad et al. (2013) [18].

\subsection{Skrining golongan senyawa}

Skrining golongan senyawa dilakukan dengan menggunakan metode spot test. Kultur suspensi sel yang diperoleh dikumpulkan menjadi satu dan diekstraksi dengan $10 \mathrm{ml}$ alkohol 96\% menggunakan metode sonikasi pada suhu $40^{\circ} \mathrm{C}$ selama 30 menit. Proses sonikasi diulang sebanyak 3 kali masing-masing dengan $10 \mathrm{ml}$ alkohol, ekstrak dikumpulkan menjadi satu kemudian dilakukan pengujian. Metode pengujian golongan senyawa yang diteliti dapat dilihat pada Tabel 1.

\subsection{Uji aktivitas antioksidan dengan metode DPPH}

Pengujian aktifitas antioksidan suspensi sel $D$. anosmum var. gigantea dilakukan menggunakan metode DPPH [21]. Dibuat larutan sampel ekstrak etanol kultur sel $D$. anosmum var. gigantea dengan konsentrasi 8281 sampai 132.500 ppm. Ekstrak etanol tanaman induk D. anosmum var. gigantea dibuat dengan konsentrasi 62.762 sampai $1.004 .200 \mathrm{ppm}$. Asam galat digunakan sebagai pembanding dengan konsentrasi 2 sampai 10 ppm. Ekstrak sampel ditambahkan larutan DPPH $40 \mathrm{ppm}$ dengan perbandingan $1: 4(40 \mu \mathrm{l}$ sampel : $160 \mu \mathrm{l}$ DPPH 40 ppm) di dalam sumuran pada 96- well microtiter plate. Setelah didiamkan selama 30 menit, dilakukan pembacaan absorbansi pada panjang gelombang $517 \mathrm{~nm}$ dengan menggunakan alat Microplate spectrophotometri (BMG Labtech SPECTROstar ${ }^{\circledR}$ Nano). Larutan asam galat sebagai pembanding diperlakukan sama seperti sampel uji. Hasil pengujian dinyatakan sebagai persen (\%) peredaman radikal bebas oleh sampel yang dihitung menggunakan rumus berikut:

$$
\text { Peredaman }(\%)=\frac{\text { Abs blanko }- \text { Abs sampel }}{\text { Abs blanko }} \times 100 \%
$$

dimana, Abs blanko adalah absorbansi DPPH + etanol tanpa penambahan sampel; Abs sampel adalah absorbansi DPPH yang direaksikan dengan sampel.

\section{Hasil dan pembahasan}

\subsection{Organoleptis dan mikroskopis sel D. anosmum var. gigantea}

Pada pengamatan organoleptis terhadap suspensi sel terlihat sel berwarna hijau dan beberapa berwarna kecoklatan dan memiliki tekstur yang kompak (Gambar 1a, Tabel 2). Warna hijau yang terdapat pada sel kalus dikarenakan adanya perkembangan kloroplas yang mengandung butir-butir klorofil [9]. Hasil pengamatan mikroskopis juga menunjukkan adanya butir klorofil (Gambar 1b). Sel yang berwarna hijau bisa jadi disebabkan oleh adanya peran dari hormon pertumbuhan BAP yang termasuk golongan sitokinin [22]. Hormon ini dapat melakukan pembentukan klorofil 


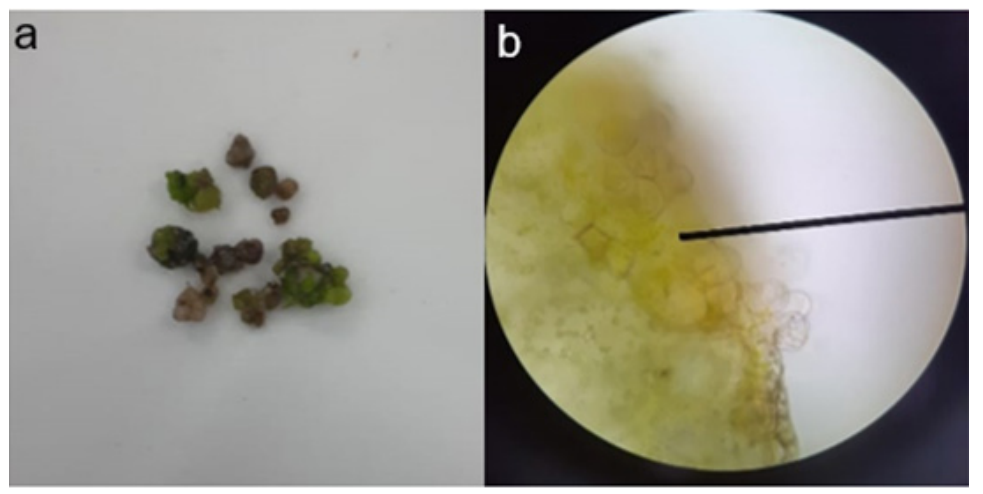

Gambar 1. Kultur kalus setelah masa kultivasi selama 14 hari (a); Hasil pengamatan mikroskopis kultur sel kalus perbesaran 400 kali (b)

Tabel 2. Hasil pengamatan organoleptis kultur suspensi sel kalus D. anosmum var. gigantea

\begin{tabular}{lllll}
\hline Metode & Kode kultur & Hari pengamatan ke- & Warna sel & Tekstur sel \\
\hline Flash shaker & E.A & 14 & Dominan hijau & Kompak \\
& E.B & 14 & Dominan hijau & Kompak \\
& E.C & 14 & Dominan coklat & Kompak \\
Bioreaktor & B.A & 14 & Dominan hijau & Kompak \\
& B.B & 14 & Dominan hijau & Kompak \\
& B.C & 14 & Dominan coklat & Kompak \\
\hline
\end{tabular}

Keterangan: E.A = Erlenmeyer A konsentrasi massa sel $10 \mathrm{mg} / 10 \mathrm{ml}$

E. $B=$ Erlenmeyer B konsentrasi massa sel $10 \mathrm{mg} / 20 \mathrm{ml}$

E.C $=$ Erlenmeyer $C$ konsentrasi massa sel $10 \mathrm{mg} / 30 \mathrm{ml}$

B.A = Bioreaktor A konsentrasi sukrosa $30 \mathrm{~g} / \mathrm{l}$

B.B = Bioreaktor B konsentrasi sukrosa $35 \mathrm{~g} / \mathrm{l}$

B.C = Bioreaktor $\mathrm{C}$ konsentrasi sukrosa $40 \mathrm{~g} / \mathrm{l}$

dan dapat menunda penuaan sel karena dapat menghambat kerusakan klorofil sehingga sel aktif membelah [23]. Suspensi sel yang dihasilkan memiliki tekstur yang relatif kompak dan padat. Kondisi yang kompak membuat sel sulit untuk dipisahkan tidak seperti kalus yang bertekstur remah yang mudah terpisah [24]. Suatu sel yang memiliki tekstur kompak disebabkan karena adanya lignifikasi pada dinding sel sehingga terjadi pelekatan pada dinding sel [25]. Hormon pertumbuhan NAA bertanggung jawab atas terbentuknya sel yang kompak dan berwarna hijau, sel yang kompak memiliki perkembangan kloroplas yang lebih baik dibandingkan dengan kalus yang remah [24].

\subsection{Pengaruh konsentrasi massa terhadap kultur suspensi sel dalam flash shaker}

Pertumbuhan suspensi sel D. anosmum var. gigantea dalam flash shaker dengan konsentrasi massa yang berbeda dapat dilihat berdasarkan nilai IP, SCV, dan PCV. Nilai parameter pertumbuhan diukur pada hari ke-0, 7, dan 14. Hasil pengukuran pada setiap sampel menunjukkan peningkatan pertumbuhan pada setiap harinya, namun pada konsentrasi massa $10 \mathrm{mg} / 30 \mathrm{ml}$ mengalami pertumbuhan yang paling buruk (Tabel 3).

Peningkatan nilai parameter pertumbuhan menunjukkan bahwa sel yang diinokulasi mengalami pertumbuhan karena kebutuhan nutrisinya terpenuhi. MS merupakan media yang memiliki kandungan garam-garam mineral yang cukup tinggi dan cocok digunakan untuk organogenesis eksplan [26]. Selain media MS media cair dilengkapi juga dengan adanya 
Tabel 3. Hasil pengamatan parameter IP, SCV, dan PCV kultur suspensi sel dalam flash shaker

\begin{tabular}{|c|c|c|c|c|c|c|c|c|c|}
\hline \multirow[t]{3}{*}{ Waktu (hari ke-) } & \multicolumn{9}{|c|}{ Kode } \\
\hline & \multicolumn{3}{|l|}{ E.A } & \multicolumn{3}{|l|}{ E.B } & \multicolumn{3}{|l|}{ E.C } \\
\hline & IP & SCV (\%) & PCV (\%) & IP & SCV (\%) & PCV (\%) & IP & SCV (\%) & PCV (\%) \\
\hline 0 & 1,00 & 0,15 & 0,1 & 1,00 & 0,76 & 0,05 & 1,00 & 0,05 & 0,03 \\
\hline 7 & 1,87 & 0,56 & 0,22 & 1,73 & 0,16 & 0,11 & 0,80 & 0,03 & 0,02 \\
\hline 14 & 2,77 & 0,61 & 0,33 & 2,60 & 0,21 & 0,16 & 0,77 & 0,02 & 0,01 \\
\hline
\end{tabular}

Keterangan: E.A = Erlenmeyer A konsentrasi massa sel $10 \mathrm{mg} / 10 \mathrm{ml}$

E.B = Erlenmeyer B konsentrasi massa sel $10 \mathrm{mg} / 20 \mathrm{ml}$

E.C $=$ Erlenmeyer $C$ konsentrasi massa sel $10 \mathrm{mg} / 30 \mathrm{ml}$

IP = Indeks Pertumbuhan

$\mathrm{SCV}=$ Settled Cell Volume

$\mathrm{PCV}=$ Packed Cell Volume

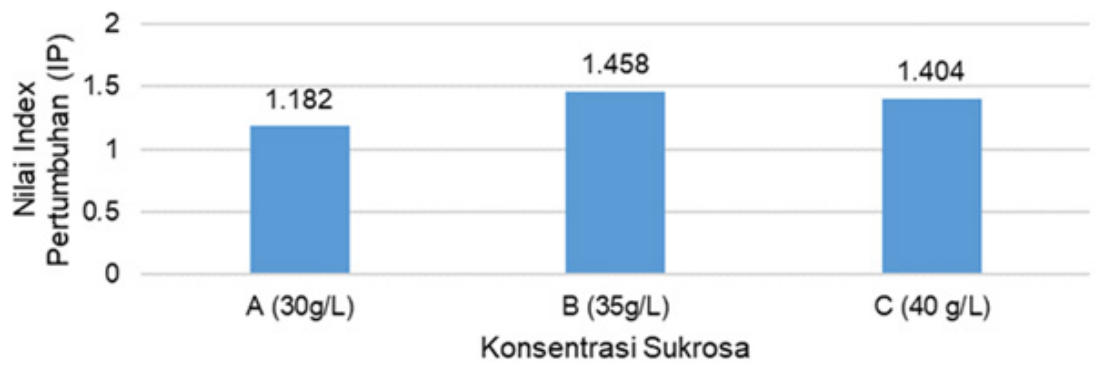

Gambar 2. Perbandingan indeks pertumbuhan kultur suspensi sel kalus D. anosmum var. gigantea pada medium dengan perbedaan konsentrasi sukrosa

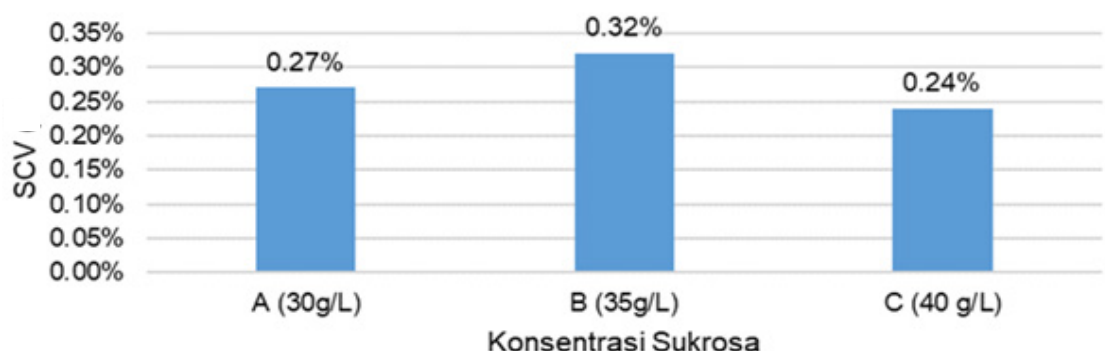

Gambar 3. Perbandingan nilai SCV kultur suspensi sel kalus D. anosmum var. gigantea pada medium dengan perbedaan konsentrasi sukrosa

hormon pertumbuhan auksin dan sitokinin yang dapat membantu pertumbuhan dari eksplan [9]. Selama masa inkubasi dilakukan agitasi menggunakan shaker, hal ini dapat menjamin homogenitas dari media sehingga nutrisi dapat tersebar secara merata, adanya agitasi berguna sebagai aerasi [27]. Hasil pengamatan menunjukkan bahwa konsentasi massa yang paling kecil yaitu $10 \mathrm{mg} / 10 \mathrm{ml}$ merupakan nilai yang paling baik dengan nilai $\mathrm{IP}=2,77$; $\mathrm{SCV}=$ 0,61\%; dan PCV $=0,33 \%$. Hal ini dikarenakan pada pemberian konsentrasi massa yang kecil, mampu menghasilkan produktivitas kalus yang lebih tinggi [13].

\subsection{Kultivasi suspensi sel dalam bioreaktor dengan perbedaan kosentrasi sukrosa}

Kultur suspensi sel D. anosmum var. gigantea pada media dengan konsentrasi sukrosa yang berbeda menunjukkan pertumbuhan yang tidak berbeda signifikan. Media cair yang mengandung $35 \mathrm{~g} / \mathrm{l}$ sukrosa pada bioreaktor B menunjukkan pertumbuhan yang paling baik berdasarkan parameter Indeks Pertumbuhan yaitu 1,458 dan perhitungan SCV didapatkan nilai 0,32\% dibandingkan dengan bioreaktor A dan C dengan sukrosa $30 \mathrm{~g} / \mathrm{l}$ 
dan $40 \mathrm{~g} / \mathrm{l}$ (Gambar 2 dan 3). Organoleptis dari sel yang dihasilkan oleh bioreaktor B menunjukkan warna dominan hijau (Tabel 2) yang mengindikasikan bahwa adanya perkembangan klorofil di dalamnya [9]. Sukrosa merupakan sumber karbon dari sel kultur dan dapat mempengaruhi hasil kultur sel yang dikultur [28]. Karbon dibutuhkan oleh sel tanaman untuk membantu dalam proses fotosintesis karena kadar $\mathrm{CO}_{2}$ yang terbatas. Dengan adanya sukrosa di dalam wadah kultur, sel dapat melakukan proses metabolisme fotomixotrofik yaitu menggunakan sumber lain untuk mendapatkan karbon [9]. Kadar sukrosa yang lebih tinggi menyebabkan stress osmotik sehingga sel mengalami pencoklatan serta pertumbuhan yang lambat kemudian mati [12]. Konsentrasi sukrosa dalam media kultur yang dianggap terlalu tinggi oleh eksplan dapat menyebabkan penurunan efisiensi sel tanaman untuk melakukan fotosintesis dengan mengurangi enzim kunci untuk fotosintesis serta tingkat klorofil [29].

\subsection{Skrining golongan senyawa dan aktivitas antioksidan}

Skrining fitokimia menggunakan metode spot

Tabel 4. Hasil skrining fitokimia tanaman dan kultur sel D. anosmum var. gigantea

\begin{tabular}{lll}
\hline Golongan senyawa & \multicolumn{2}{l}{ Hasil* } \\
\cline { 2 - 3 } & Tanaman & Kultur sel \\
\hline Alkaloid & - & - \\
Steroid & - & - \\
Terpenoid & + & + \\
Saponin & - & - \\
Fenol & + & + \\
Tanin & - & - \\
Flavonoid & - & - \\
\hline * : Positif kandungan senyawa; - : Negatif kandu- \\
ngan senyawa
\end{tabular}

test yang dilakukan pada ekstrak etanol dari suspensi sel $D$. anosmum var. gigantea menunjukkan hasil positif pada golongan senyawa terpenoid dan fenolik (Tabel 4). Pada umumnya anggrek spesies Dendrobium mengandung alkaloid den- drobin [6]. Selain alkaloid, Dendrobium juga memiliki golongan senyawa tanin dan fenol [7]. Pada pengujian golongan senyawa alkaloid dan flavonoid negatif, hal ini disebabkan kemungkinan golongan senyawa tersebut terdapat dalam konsentrasi yang sangat kecil sehingga tidak terdeteksi oleh pereaksi. Metode spot test merupakan metode pewarnaan dan pengendapan. Beberapa riset melaporkan bahwa D. anosmum var. gigantea memiliki kandungan flavonoid. Golongan senyawa flavonoid dan fenolik diketahui dapat digunakan sebagai agen antioksidan [30,31].

Ekstrak etanol dari sel hasil kultur dan tanaman induk dari anggrek D. anosmum var. gigantea diuji aktivitas antioksidannya menggunakan uji radikal DPPH. Larutan asam galat digunakan sebagai kontrol positif. Radikal bebas DPPH yang memiliki elektron tidak berpasangan memiliki warna ungu [32]. Warna ungu akan berubah menjadi ungu muda atau kuning ketika larutan DPPH dicampur dengan senyawa bahan alam yang dapat mereduksi larutan radikal DPPH [33]. Penangkapan atom hidrogen menyebabkan ikatan rangkap terkonjugasi pada DPPH berkurang sehingga terjadi penurunan intensitas warna dan absorbansi.

Hasil pembacaan menggunakan 96-well microtiter plate didapatkan bahwa absorbansi yang paling kecil didapatkan dari sampel dengan konsentrasi paling tinggi. Persentase peredaman tertinggi didapatkan dari sampel kultur sel dengan rata-rata $76 \%$ pada konsentrasi 132.500 ppm (Tabel 5), sedangkan pada sampel tanaman induk didapatkan persentase peredaman yang lebih kecil dibandingkan dengan kultur kalus yaitu 57\% pada konsentrasi ekstrak 502.100 ppm (Tabel 5). Nilai IC $_{50}$ dihitung untuk melihat kekuatan aktivitas antioksidan dari sampel. Ekstrak kultur sel menunjukkan nilai $\mathrm{IC}_{50}$ lebih kecil dibandingkan dengan ekstrak tanaman induk yaitu 53.930 ppm (Tabel 5). Dari hasil perhitungan $\mathrm{IC}_{50}$ didapatkan bahwa aktivitas antioksidan dari kultur sel lebih baik dibandingkan tanaman induk namun masih 
Tabel 5. Nilai inhibisi dan $\mathrm{IC}_{50}$ kultur sel dan tanaman $D$. anosmum var. gigantea terhadap DPPH

\begin{tabular}{llll}
\hline Sampel & Konsentrasi (ppm) & Inhibisi (\%) & IC $_{50}$ (ppm) \\
\hline Ekstrak suspensi sel kalus & 132.500 & $76 \pm 1,92$ & 53.930 \\
& 66.250 & $61 \pm 3,09$ & \\
& 33.125 & $52 \pm 2,58$ & \\
& $16.562,5$ & $32 \pm 4,59$ & \\
Ekstrak tanaman induk & $8.281,25$ & $24 \pm 1,93$ & 353.948 \\
& 502.100 & $57 \pm 7,62$ & \\
& 251.050 & $51 \pm 1,92$ & \\
Asam galat* & 125.525 & $37 \pm 2,82$ & \\
& $62.762,5$ & $27 \pm 2,04$ & \\
& 10 & 58,77 & \\
& 8 & 45,55 & \\
& 4 & 44,27 & \\
& 6 & 33,08 & \\
\end{tabular}

*kontrol positif

tergolong dalam kategori sangat lemah karena memiliki nilai $\mathrm{IC}_{50}$ lebih dari 200 ppm [34]. Diketahui pada spesies Dendrobium yang lain yaitu D. speciosum dan 4 spesies Dendrobium yang dikultivasi di Thailand yaitu Sonia, Sonia Pink, Snow Withe, dan Shavin White memiliki potensi sebagai antioksidan. Potensi Antioksidan yang ada dalam tanaman tersebut karena adanya kandungan polifenol dan flavonoid yang cukup [35, 36]. Selain senyawa polifenol dan flavonoid, senyawa derivat bibenzyl-dihydrophenanthrene baru yang ditemukan pada D. pharsii yang kemudian dinamai (-)-dendropharisiol menunjukkan aktivitas antioksidan yang tinggi dibandingkan senyawa bibenzyl yang lain [2].

\section{Kesimpulan}

Studi ini menunjukkan bahwa dengan peningkatan konsentrasi massa suspensi sel kalus yang ditanam dengan metode flash shaker, tidak mengalami peningkatan yang signifikan. Pertumbuhan yang paling baik didapatkan pada konsentrasi massa $10 \mathrm{mg} / 10 \mathrm{ml}$ dengan nilai $\mathrm{IP}=2,77$; SCV = 0,61\%; dan PCV = 0,33\%. Peningkatan kadar sukrosa berpengaruh terhadap pertumbuhan suspensi sel kalus di dalam bioreaktor. Kadar sukrosa paling optimal untuk suspensi sel kalus D. anosmum var. gigantea adalah $35 \mathrm{~g} / \mathrm{l}$ dengan nilai IP $=1,458$ dan SCV $=0,32 \%$, serta dilihat berdasarkan morfologis sel yang dominan hijau. Suspensi sel anggrek D. anosmum var. gigantea memiliki aktivitas antioksidan namun memiliki potensi yang sangat kecil. Golongan seyawa yang ditemukan di dalam sel dan tanaman induk D. anosmum var. gigantea adalah terpenoid dan fenol. Aktivitas antioksidan yang dihasilkan oleh sel memiliki nilai IC $_{50}$ sebesar 53.930 ppm, namun termasuk dalam kategori sangat lemah.

\section{Daftar Pustaka}

1. Hidayati NZ, Saptadi D, Soetopo L. Analisis hubungan kekerabatan 20 spesies anggrek Dendrobium berdasarkan karakter morfologi. Jurnal produksi Tanaman. 2016;4(4):291-7.

2. Kongkatitham V, Muangnoi C, Kyokong N, Thaweesest W, Likhitwitayawuid K, Rojsitthisak P, Sritularak B. Anti-oxidant and antiinflammatory effects of new bibenzyl derivatives from Dendrobium parishii in hydrogen peroxide and lipopolysaccharide treated RAW264. 7 cells. 
Phytochemistry Letters. 2018;24:31-8.

3. Guo Z, Zhou Y, Yang J, Shao X. Dendrobium candidum extract inhibits proliferation and induces apoptosis of liver cancer cells by inactivating $\mathrm{Wnt} / \beta$-catenin signaling pathway. Biomedicine \& Pharmacotherapy. 2019;110:3719.

4. Gong CY, Yu ZY, Lu B, Yang L, Sheng YC, Fan YM, Ji LL, Wang ZT. Ethanol extract of Dendrobium chrysotoxum Lindl ameliorates diabetic retinopathy and its mechanism. Vascular pharmacology. 2014;62(3):134-42.

5. Inthongkaew P, Chatsumpun N, Supasuteekul C, Kitisripanya T, Putalun W, Likhitwitayawuid K, Sritularak B. $\alpha$-Glucosidase and pancreatic lipase inhibitory activities and glucose uptake stimulatory effect of phenolic compounds from Dendrobium formosum. Revista Brasileira de Farmacognosia. 2017;27(4):480-7.

6. Andiani Y. Usaha pembibitan anggrek dalam botol. Yogyakarta: Pustaka Baru Press; 2008.

7. Krisnawan AH, Palupi S, Suhartina S, Saputri AE, Ari IG, Wandhini NM, Yunita O. Karakterisasi Senyawa Metabolit pada Kultur Anggrek Dendrobium anosmum-gigantea. MPI (Media Pharmaceutica Indonesiana). 2020;3(1):10-8.

8. Martin KP, Madassery J. Rapid in vitro propagation of Dendrobium hybrids through direct shoot formation from foliar explants, and protocorm-like bodies. Scientia Horticulturae. 2006;108(1):95-9.

9. Bhatia S. Plant tissue culture. In: Modern Applications of Plant Biotechnology in Pharmaceutical Sciences. Elsevier Inc.; 2015:31107.

10. Nartop P. Engineering of Biomass Accumulation and Secondary Metabolite Production in Plant Cell and Tissue Cultures. In: Plant Metabolites and Regulation under Environmental Stress. Elsevier Inc.; 2018:169-94.

11. Widiastoety D. Pengaruh auksin dan sitokinin terhadap pertumbuhan planlet anggrek Mokara. Jurnal Hortikultura. 2016;24(3):230-8.

12. Chin WY, Annuar MS, Tan BC, Khalid N. Evaluation of a laboratory scale conventional shake flask and a bioreactor on cell growth and regeneration of banana cell suspension cultures. Scientia Horticulturae. 2014;172:39-46.

13. Chan LK, Koay SS, Low PH, Boey PL. Effect of plant growth regulators and subculture frequency on callus culture and the establishment of Melastoma malabathricum cell suspension culture for the production of pigments. Biotechnology. 2008;7(4):678-85.

14. Paek KY, Chakrabarty D, Hahn EJ. Application of bioreactor systems for large scale production of horticultural and medicinal plants. Plant Cell, Tissue and Organ Culture. 2005;81:287-300.

15. Sholikhah M. Inisiasi Kultur Suspensi Sel Anggrek (Dendrobium anosmum gigantea). Skripsi tidak dipublikasikan. Surabaya: Fakultas Farmasi Universitas Surabaya; 2018.

16. Yonathan VS. Optimasi Konsentrasi Massa Kultur Suspensi Sel Dendrobium anosmum var. gigantea dalam Medium Murashige and Skoog (MS). Skripsi tidak dipublikasikan. Surabaya: Fakultas Farmasi Universitas Surabaya; 2019.

17. Maulana I. Optimasi Aliran Udara Bioreaktor Bubble Column Terhadap Kultur Suspensi Sel Dendrobium Anosmum var. Gigantea. Skripsi tidak dipublikasikan. Surabaya: Fakultas Farmasi Universitas Surabaya; 2019.

18. Farjaminezhad R, Zare N, Zakaria RA, Farjaminezhad M. Establishment and optimization of cell growth in suspension culture of Papaver bracteatum: a biotechnology approach for thebaine production. Turkish journal of biology. 2013;37(6):689-97.

19. Hanani E. Analisis Fitokimia. Hadinata TVD, Hanif A, editors. Jakarta: Penerbit Buku Kedokteran EGC; 2014.

20. Savithramma N, Rao ML, Suhrulatha D. Screening of medicinal plants for secondary metabolites. Middle-East Journal of Scientific Research. 2011;8(3):579-84.

21. Molyneux P. The use of the stable free radical diphenylpicrylhydrazyl (DPPH) for estimating antioxidant activity. Songklanakarin J. sci. technol. 2004;26(2):211-9. 
22. Lizawati. Induksi Kalus Embriogenik Dari Eksplan Tunas Apikal Tanaman Jarak Pagar (Jatropha Curcas L.) Dengan Penggunaan 2,4 D Dan Tdz.

23. Muliati, Nurhidyah T, Nurbaiti. Pengaruh NAA, BAP dan kombinasinya pada media MS terhadap perkembangan eksplan Sansevieria macrophylla secara in vitro. JOM FAPERTA; 2017;4(1):1-13.

24. Boamponsem GA, Leung DW. Use of compact and friable callus cultures to study adaptive morphological and biochemical responses of potato (Solanum tuberosum) to iron supply. Scientia Horticulturae. 2017;219:161-72.

25. Kumar U. Methods in plant tissue culture. Jodhpur: Agrobios; 2008.

26. Hoesen DS, Witjaksono W, Sukamto LA. Induksi kalus dan organogenesis kultur in vitro Dendrobium lineale Rolfe. Berita Biologi. 2008;9(3):333-41.

27. Hendaryono DPS, Wijayani A. Teknik Kultur Jaringan: Pengenalan dan Petunjuk Perbanyakan Tanaman Secara Vegetatif Modern. Yogyakarta: Kanisius; 1994.

28. Razdan M. Introduction to Plant Tissue Culture. New Hampshire: Science Publisher; 2003.

29. Bhatia S, Sharma K, Dahiya R, Bera T. Modern applications of plant biotechnology in pharmaceutical sciences. Academic Press; 2015.

30. Olszowy M. What is responsible for antioxidant properties of polyphenolic compounds from plants?. Plant Physiology and Biochemistry. 2019;144:135-43.

31. Procházková D, Boušová I, Wilhelmová N. Antioxidant and prooxidant properties of flavonoids. Fitoterapia. 2011;82(4):513-23.

32. Rizkayanti R, Diah AW, Jura MR. Uji aktivitas antioksidan ekstrak air dan ekstrak etanol daun kelor (Moringa oleifera LAM). Jurnal Akademika Kimia. 2017;6(2):125-31.

33. Setiawan F, Yunita O, Kurniawan A. Uji Aktivitas Antioksidan Ekstrak Etanol Kayu Secang (Caesalpinia sappan) Menggunakan Metode DPPH, ABTS,dan FRAP. MPI (Media Pharmaceutica Indonesiana). 2018;2(2):82-9.

34. Bahriul P, Rahman N. Uji Aktivitas Antioksidan Ekstrak Etanol Daun Salam (Syzyngium polyanthum) Dengan Metode DPPH. Jurnal Akademika Kimia. 2014;3(3):368-74.

35. Moretti M, Cossignani L, Messina F, Dominici L, Villarini M, Curini M, Marcotullio MC. Antigenotoxic effect, composition and antioxidant activity of Dendrobium speciosum. Food chemistry. 2013;140(4):660-5.

36. Athipornchai A, Jullapo N. Tyrosinase inhibitory and antioxidant activities of Orchid (Dendrobium spp.). South African Journal of Botany. 2018;119:188-92. 